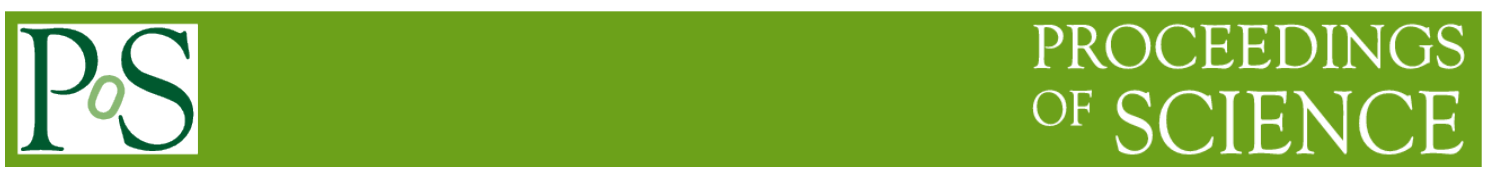

\title{
The Have and Have nots - their strategies for Nuclear Zero
}

\author{
Riccardo Antonini ${ }^{1}$ \\ Istituto Buddista Italiano Soka Gakkai, \\ Via di Bellagio, 2e I-50141 \\ Firenze, Italy \\ E-mail: riccardo.antoninini-abcdeposte.it
}

\begin{abstract}
Until very recently all the issues concerning nuclear armaments, including disarmament, were the exclusive realm of the nuclear-armed states. In fact the Nuclear Nonproliferation Treaty itself (NPT) divided the world into the Have and Have Nots. This divide was reached by freezing the situation on the date of January 1, 1967 (art. IX.3 of NPT). Of course the number of nuclear-armed states later became greater than the number of "nuclear weapon states" as defined in art. IX. Anyhow the great quantitative divide among the super powers and any other nuclear-armed state de facto limited the players in this field even more to just United States and Soviet Union (now Russia). Then something unexpected happened: most of the non nuclear-armed States, albeit with a few exceptions, stepped forward, declaring that the survival of mankind was by definition, a matter of universal concern. Hence, in their view, nuclear disarmament had to be discussed among the representatives of all nations, even if this meant at least initially, that the discussions would take place without the participation of all or even any of the nuclear-armed states. The aim of this paper is, after presenting certain critical aspects of the current situation of nuclear armaments, to illustrate the strategies of non nuclear-armed states towards total nuclear disarmament. This will be attempted in the simplest possible way albeit not an exhaustive one.
\end{abstract}

Frontier Research in Astrophysics - II

23-28 May 2016

Mondello (Palermo), Italy

${ }^{1}$ Speaker 


\section{Introduction}

"What then is the point of national security guaranteed by nuclear weapons, the use of which would inevitably produce catastrophic consequences and result in immense suffering and sacrifice throughout the world? What exactly is it that is protected by a security regime premised on the possibility of inflicting irreparable damage and devastation on vast numbers of people? Is this not a system in which the true objective of national security - protecting people and their lives - has in fact been forsaken?"

[Daisaku Ikeda

Peace Proposal to the United Nations - 2016]

The data and views in the present paper are reported with the sole purpose of giving the widest and clearest possible picture of a major paradigm shift in nuclear disarmament which has recently come to the fore. This will be done in compatibility with the limits of space of a paper of this kind. It is important to note that no endorsement whatsoever is implied of any of the reported positions. Moreover the new paradigm still coexists with previous ones as well as with other new ones.

Put it simply: new types of questions, like the one in the epigraph, have begun to be asked by new groups: NGOs, religious people and some governments. All this obviously implies new ways of looking at nuclear disarmament issues.

It is out of the scope of this paper to establish which one of these new ways is best, the only scope of it is to illustrate some of them. Comparison with more long standing scopes has been unavoidable though. Again the author tries to avoid any intentional value judgements.

\subsection{A brief history}

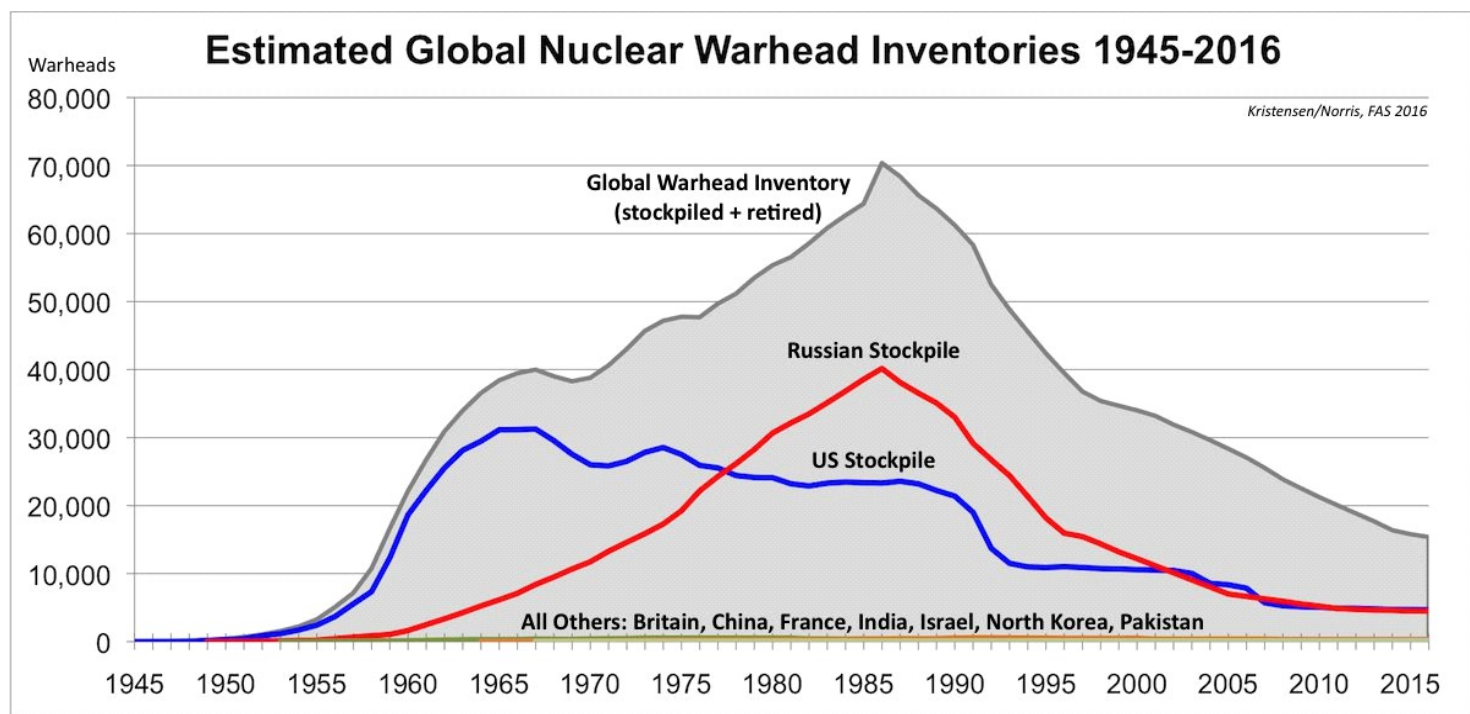

Fig. 1.1: History of nuclear stockpiles

After looking at the historical data of nuclear stockpiles Fig. 1.1, Fig. 1.2 it is tempting to conclude that, once the Cold War surges had finsished, the decline of US inventories has been 
followed, after a delay, by Russia and continues to date. It would appear total nuclear disarmament would just a matter of time.

However looking at the US expenditures Fig. 1.3 the situation may look to some quite different. Albeit with some oscillations the long term trend seems to indicate an overall substantial growth of these expenditures. The nuclear budgets of Russia is more difficult to assess but the general trend is also towards an increase. [1].

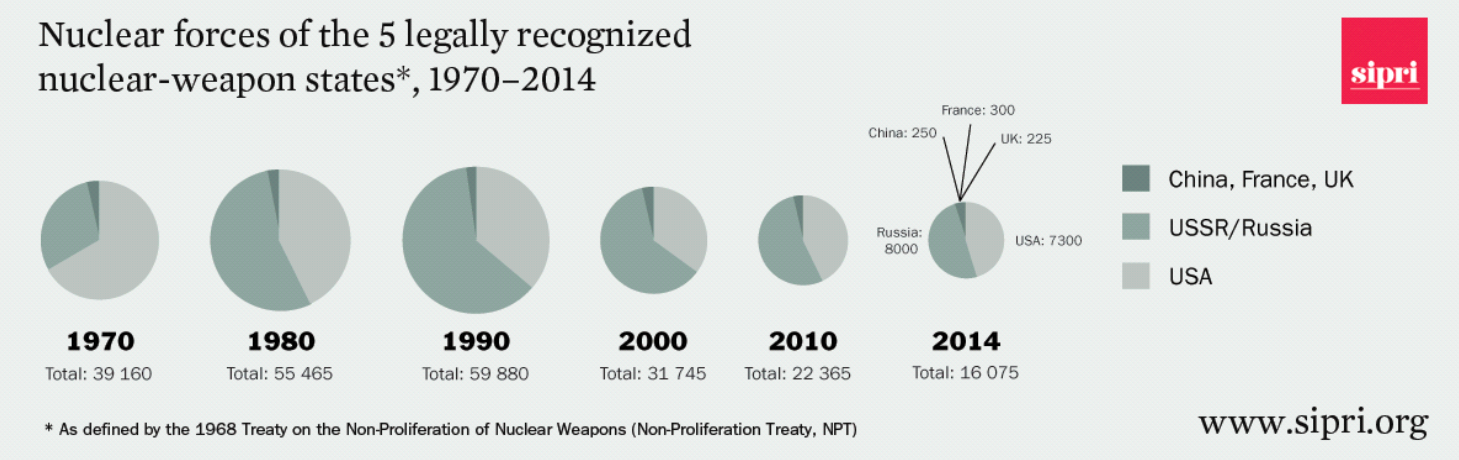

Fig. 1.2: Breakdown of nuclear stockpile (historical view)

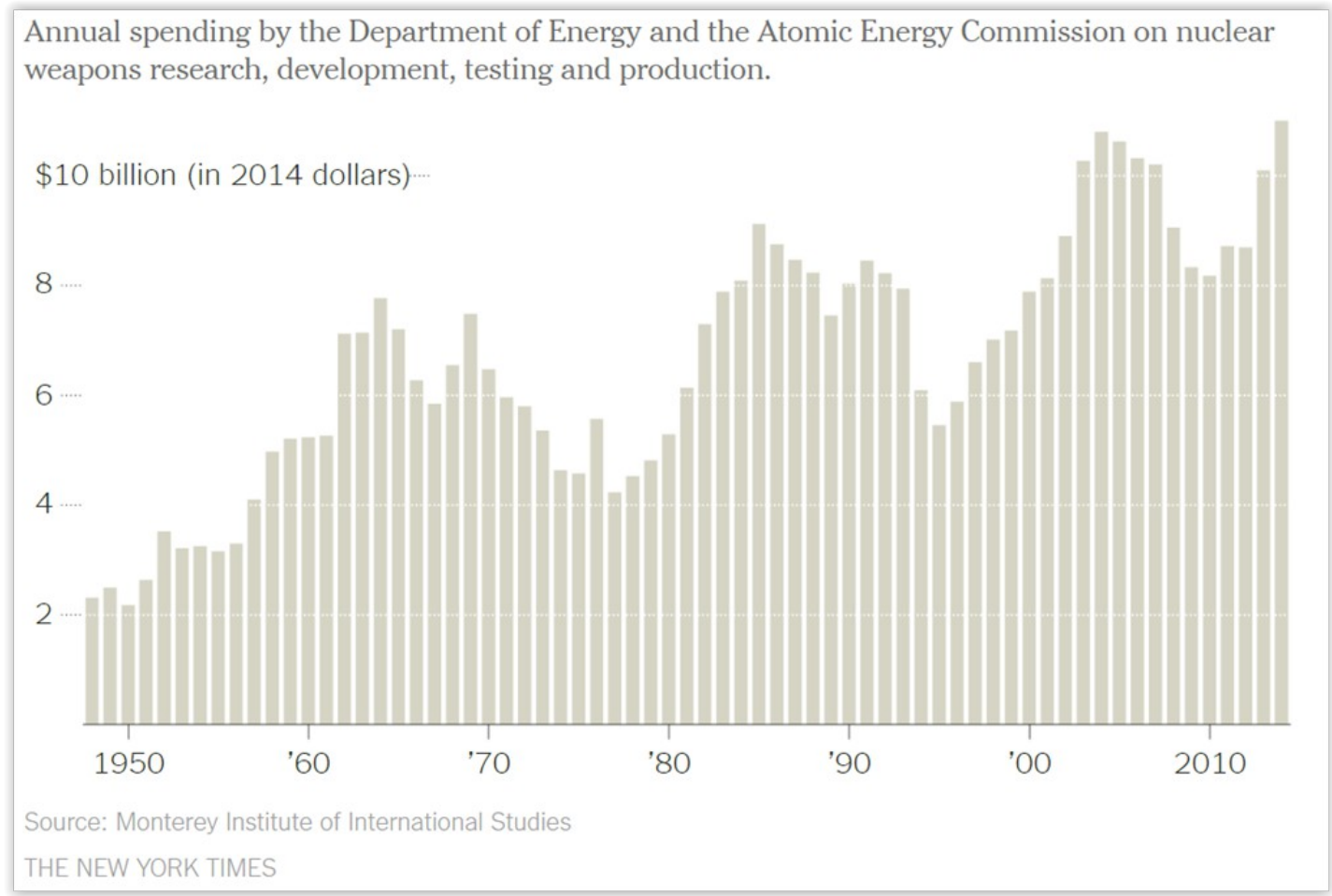

Fig. 1.3: US Annual Spending (DOD and AEC combined) 


\subsection{The current situation}

Global share of nuclear weapons in January 2016

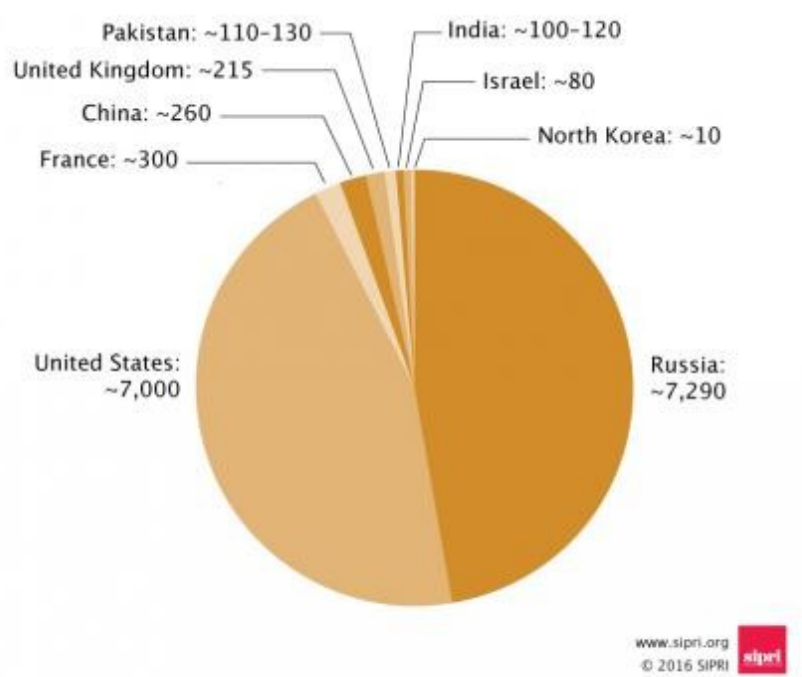

Fig. 1.4: SIPRI Most recent breakdown of global nuclear stockpile

The current situation Fig. 1.4, as far as quantitative size of nuclear inventories is concerned, looks, generally and very broadly speaking stationary [see as well Fig. 1.2]; the two big players and the rest of the nuclear-armed states following at orders of magnitude.

This has implied that, de facto, the responsibility of nuclear disarmament was felt to be (almost) exclusively that of the US and Russia. The rest of the governments could only hope for certain outcomes to happen.

Capitalizing, among other events, on a widespread dissatisfaction with the implementation and interpretation of NPT article $\mathrm{VI}^{2}$ which continued to come to the fore for example at the NPT Review Conferences, more and more governments of nonnuclear armed states and NGOs begun to propose new ways out of the "nuclear impasse".

In order to do so it became necessary to take into account new quantitative and geopolitical dimensions of the problem. In the following, an estimate of these dimensions will be attempted. These new dimensions were obviously not the sole cause and motivation for such a bold paradigm shift, nevertheless the scope of this paper is to

\footnotetext{
${ }^{2}$ Article VI

"Each of the Parties to the Treaty undertakes to pursue negotiations in good faith on effective measures relating to cessation of the nuclear arms race at an early date and to nuclear disarmament, and on a treaty on general and complete disarmament under strict and effective international control."
} 
focus on them in order to cast some light on some facts not so often evidenced in this realm.

A brief analysis of those new dimensions follows.

\subsection{A more detailed analysis}

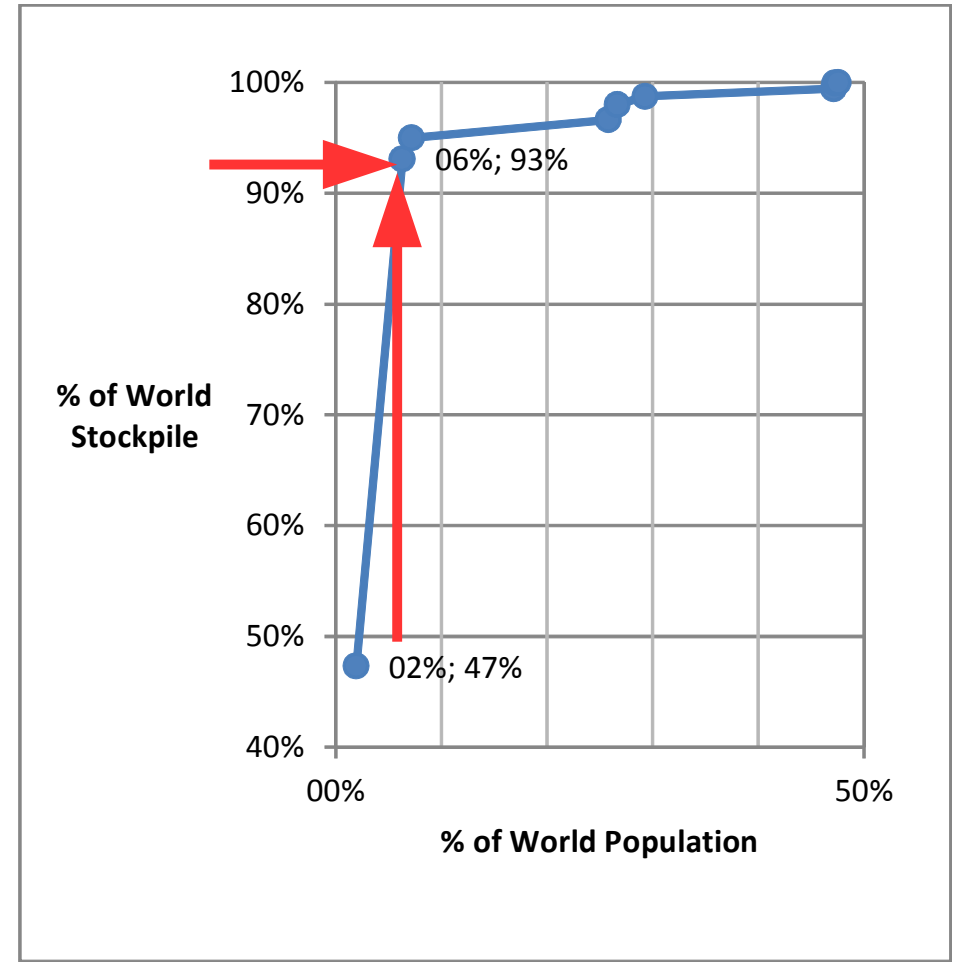

Fig. 1.5: How many people are "defended" by so many warheads (Authors Elaborations on Public Domain Data)

\section{GNWI.}

(

\begin{tabular}{|c|c|c|c|c|c|c|c|c|c|}
\hline Country & $\begin{array}{l}\text { Estimated } \\
\text { Stockpile } \\
\text { (Max) }\end{array}$ & Population & $\begin{array}{l}\text { Warheads } \\
\text { Per } \\
\text { Million } \\
\text { Citizens }\end{array}$ & $\begin{array}{l}\text { Warhead } \\
\text { Incr \% }\end{array}$ & $\begin{array}{l}\text { Warhead } \\
\text { Incremental }\end{array}$ & $\begin{array}{l}\text { Populati } \\
\text { on } \\
\text { increme } \\
\text { ntal \% }\end{array}$ & $\begin{array}{l}\text { Population } \\
\text { Incremental } \\
\text { (Millions) }\end{array}$ & $\begin{array}{l}\text { Warheads } \\
\% \text { of Total }\end{array}$ & $\begin{array}{l}\text { Population } \\
\% \text { ofTotal }\end{array}$ \\
\hline Russia & 7,500 & $143,439,832$ & 52.3 & $47.3 \%$ & 7,500 & $1.9 \%$ & 143 & $47.3 \%$ & $1.9 \%$ \\
\hline United States & 7,260 & $324,118,787$ & 22.4 & $93.1 \%$ & 14,760 & $6.3 \%$ & 468 & $45.8 \%$ & $4.4 \%$ \\
\hline France & 300 & $64,668,129$ & 4.6 & $95.0 \%$ & 15,060 & $7.2 \%$ & 532 & $1.9 \%$ & $0.9 \%$ \\
\hline China & 260 & $1,382,323,332$ & 0.2 & $96.6 \%$ & 15,320 & $25.8 \%$ & 1,915 & $1.6 \%$ & $18.6 \%$ \\
\hline United Kingdom & 215 & $65,111,143$ & 3.3 & $98.0 \%$ & 15,535 & $26.7 \%$ & 1,980 & $1.4 \%$ & $0.9 \%$ \\
\hline Pakistan & 120 & $192,826,502$ & 0.6 & $98.8 \%$ & 15,655 & $29.3 \%$ & 2,172 & $0.8 \%$ & $2.6 \%$ \\
\hline India & 110 & $1,326,801,576$ & 0.1 & $99.4 \%$ & 15,765 & $47.1 \%$ & 3,499 & $0.7 \%$ & $17.9 \%$ \\
\hline Israel & 80 & $8,192,463$ & 9.8 & $99.9 \%$ & 15,845 & $47.2 \%$ & 3,507 & $0.5 \%$ & $0.1 \%$ \\
\hline North Korea & 8 & $25,281,327$ & 0.3 & $100.0 \%$ & 15,853 & $47.6 \%$ & 3,533 & $0.1 \%$ & $0.3 \%$ \\
\hline Total & 15,853 & $3,532,763,091$ & 4.5 & & & & & & \\
\hline WorldPopul & 15,853 & $7,424,348,000$ & 2.1 & & & & & & \\
\hline HaveNots & 15,853 & $3,891,584,909$ & 4.1 & & & & & & \\
\hline
\end{tabular}

Fig. 1.6: Single and cumulative figures of Nuclear Warheads and Population by

Country (Author's Calculations using Public Domain Data) 


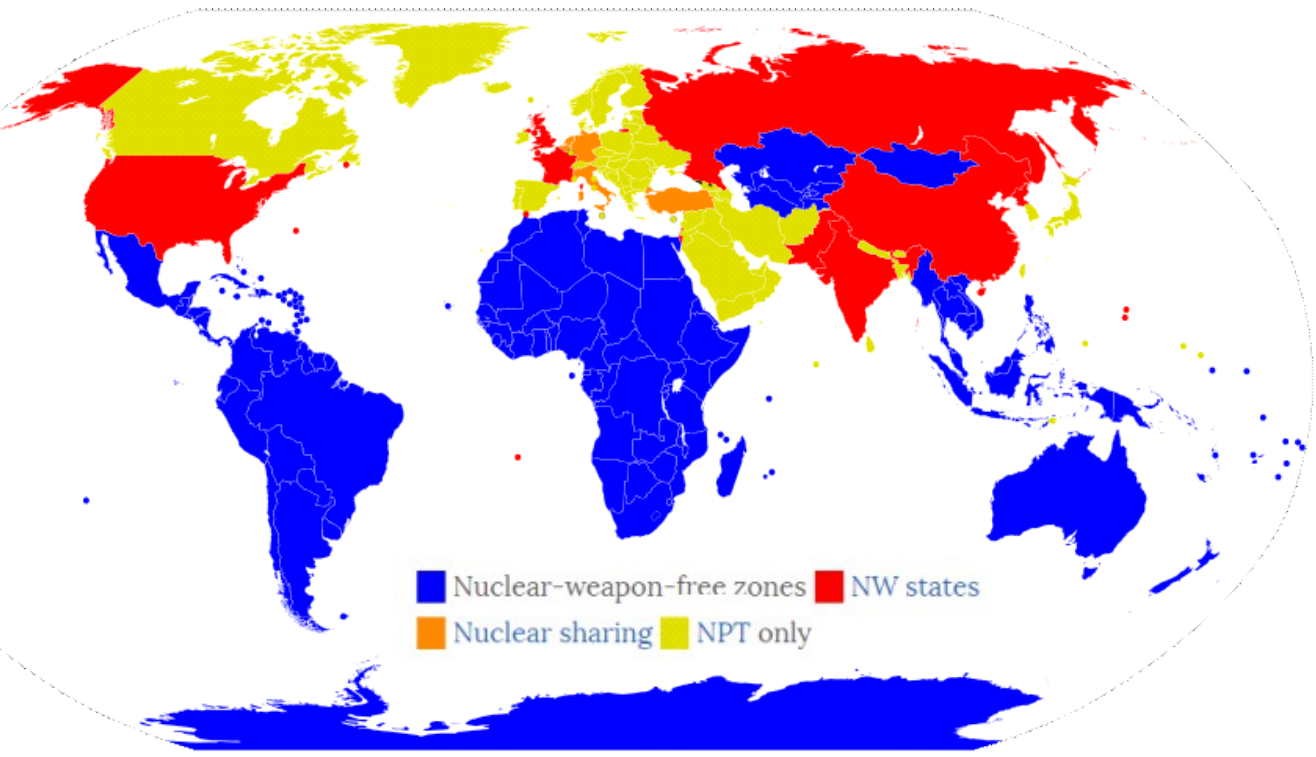

Fig. 1.7: Geographical distribution of Haves and Haves Not (credit:Wikipedia-Creative Commons Attribution-Share Alike 3.0)

Looking at the above map ${ }^{3}$, Fig. 1.7, it is evident that if we exclude the vast surface area of Russia which only hosts $1.9 \%$ of the world's population, the total surface of the world occupied by Nuclear Armed States would only be a small percentage of the total. Even adding Russia, they still occupy less than $50 \%$ of the world's dry land.

\section{The road to zero - the strategies of nuclear and non nuclear-armed states}

\subsection{Strategies of Nuclear-armed states}

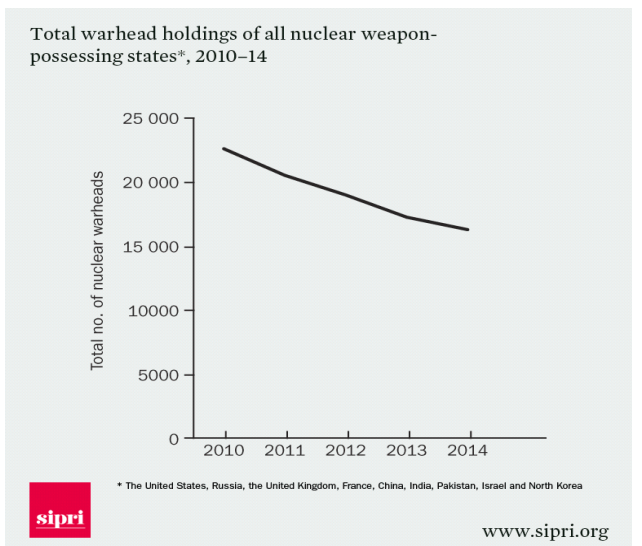

Fig. 1.8: 2010-2014 global trend in warheads holdings

This asymptotic trend combined with the upward movement in expenditure and financial magnitude [2], [3] and scope [4] of the programs of the so called "modernization" (of nuclear weapons systems) are in direct conflict with the official position of US President Barack Obama as stated in Fig. 1.9

\footnotetext{
${ }^{3}$ The map uses "Mercator" projection which is well known to penalize, as far as area sizes are concerned, the southern hemisphere)
} nuclear arsenals continued until very recently albeit their inventories combined look at present as if they were heading towards an "asymptotic" level of around 15,000.Fig. 1.8

The trend is not promising.

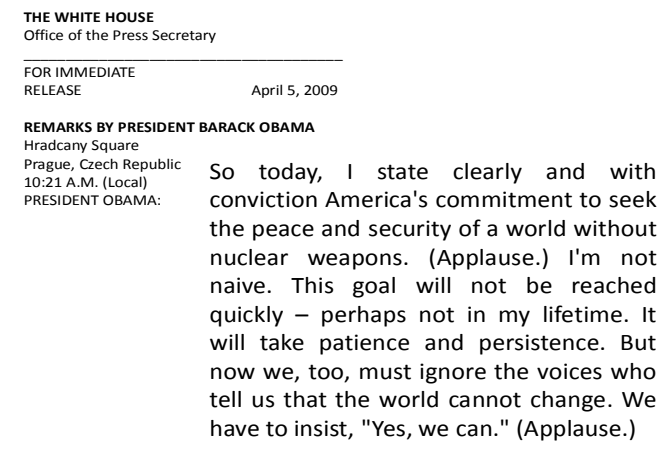

Fig. 1.9: US President Barack Obama "Prague Speech" 


\section{NSS THE WALLSTREEET JOURNAL.}

January 15,2008

OPINION

DOW JONES REPRINTS

\section{Toward a Nuclear-Free World}

By GEORGE P. SHULTZ, WILLIAM J. PERRY, HENRY A. KISSINGER and SAM NUNN

January 15,2008

The accelerating spread of nuclear weapons, nuclear know-how and nuclear material has brought us to a nuclear tipping point. We face a very real possibility that the deadliest weapons ever invented could fall into dangerous hands.

The steps we are taking now to address these threats are not adequate to the danger. With nuclear weapons more widely available, deterrence is decreasingly effective and increasingly hazardous.

Fig. 1.10: H. Kissinger et al. - The Wall Street Journal - "Towards a Nuclear Free World" article (excerpt)

and many other statements by other senior officials Fig. 1.10

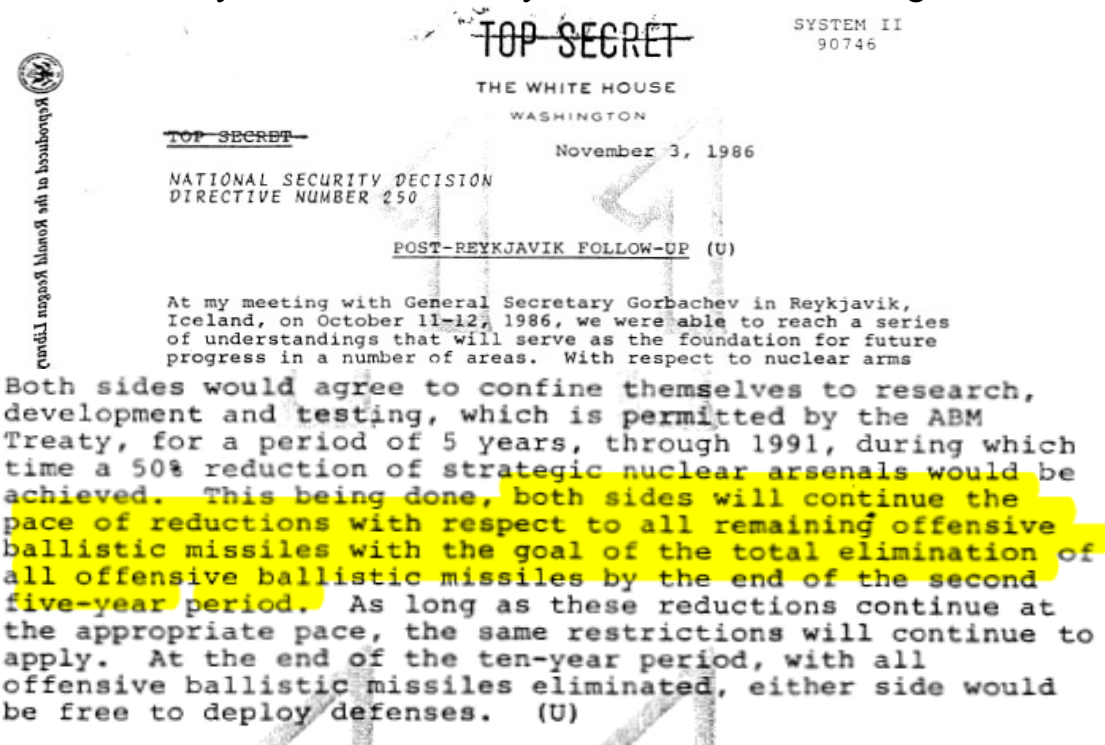

Fig. 1.11: Post Reykjavik Follow-up memorandum

Added to this, the "u-turn" taken by both US and USSR after the discussions in Reykjavik in October 1986 Fig. 1.11 must have seemed appalling to the non nuclear armed states. 


\subsection{Strategies of Non Nuclear-armed states}

In order to illustrate the announced new views two approaches will be illustrated in some detail considering them somehow paradigmatic. Again no endorsement is implied.

\subsubsection{UN Fold Zero}

"The aim of zero nuclear weapons - the prohibition and complete elimination of nuclear weapons under strict and effective international control - was first affirmed by

UN General Assembly resolution 1 (I) on January 24, 1946.

A reliance on nuclear deterrence by some countries in response to regional and international tensions since then has thwarted the achievement of this goal. However, a number of recent developments bring this goal into sight. These include globalisation, the strengthening of international law, a growing public aversion to all weapons of mass destruction and the increasing effectiveness of the United Nations and other cooperative security mechanisms to address core security issues." [5]

"UNFOLD ZERO called on those countries reliant on nuclear weapons to relinquish nuclear deterrence policies - as most other countries in the world have already done - in order to be able to join nuclear abolition negotiations. UNFOLD ZERO highlighted common security approaches and mechanisms - such as those available through the United Nations - as being less destabilizing, less threatening and more suitable for the 21st Century than the reliance on annihilation of other countries with nuclear weapons.

UNFOLD ZERO called on non-nuclear countries to take action to prohibit nuclear weapons - nationally, regionally and internationally - without waiting for the nuclear reliant countries. " [6]

The last line (emphasis mine) constitutes probably the most evident departure from the approaches to nuclear disarmament based on bi-lateral negotiations between the two major players.

Another obvious departure is constituted by the reliance on the successfully renewed and reinforced role of UN General Assembly in contrast with the role of the Security Council whose composition coincides with the one of the nuclear weapons state as defined by art. IX.3 of NPT. 


\subsubsection{Humanitarian Pledge}

Seventieth session

Agenda item $97(b)$

\section{Resolution adopted by the General Assembly on 7 December 2015}

[on the report of the First Committee (A/70/400)]

70/48. Humanitarian pledge for the prohibition and elimination of nuclear weapons

The General Assembly,

Ever mindful of the unacceptable harm that victims of nuclear weapon explosions and nuclear testing have experienced, and recognizing that the rights and needs of victims have not yet been adequately addressed,

Understanding that the immediate, medium-term and long-term consequences of a nuclear weapon explosion would be significantly graver than was understood in the past and would not be constrained by national borders but have regional or even global effects, potentially threatening the survival of humanity,

Recognizing the complexity of and relationship between these consequences for, inter alia, health, the environment, infrastructure, food security, climate, development, social cohesion, displacement and the global economy, which would be systemic and potentially irreversible,

Aware that the risk of a nuclear weapon explosion is significantly greater than previously assumed and is indeed increasing with increased proliferation, the lowering of the technical threshold for nuclear weapon capability, the ongoing modernization of nuclear weapon arsenals in States possessing nuclear weapons and the role that is attributed to nuclear weapons in the nuclear doctrines of such States,

Cognizant that the risk of the use of nuclear weapons, with its unacceptable consequences, can be avoided only when all nuclear weapons have been eliminated,

Emphasizing that the consequences of a nuclear weapon explosion and the risks associated with nuclear weapons concem the security of all humanity and that all States share the responsibility to prevent any use of nuclear weapons,

Emphasizing also that the scope of the consequences of a nuclear weapon explosion and the associated risks raise profound moral and ethical questions that go beyond debates about the legality of nuclear weapons,

Mindful that no national or international capacity exists that would adequately respond to the human suffering and humanitarian harm that would result from a nuclear weapon explosion in a populated area, and that such capacity most likely will never exist, 
Affirming that it is in the interest of the very survival of humanity that nuclear weapons are never used again, under any circumstances,

Reiterating the crucial role that international organizations, relevant entities of the United Nations, the International Red Cross and Red Crescent Movement, elected representatives, academia and civil society play in advancing the shared objective of a nuclear-weapon-free world,

Recalling the three international conferences convened, respectively, by Norway in March 2013, Mexico in February 2014 and Austria in December 2014 on the humanitarian impact of nuclear weapons, and the compelling evidence presented at these conferences,

Welcoming the fact that 120 States have drawn inescapable conclusions from the evidence on the humanitarian impact of nuclear weapons and, consequently, supported or endorsed the Humanitarian Pledge, ${ }^{3}$

1. Stresses the importance of having fact-based discussions and presenting findings and compelling evidence on the humanitarian impact of nuclear weapons in all relevant forums and within the United Nations framework, as they should be at the centre of all deliberations and the implementation of obligations and commitments with regard to nuclear disarmament;

2. Appeals to all States to follow the imperative of human security for all and to promote the protection of civilians against risks stemming from nuclear weapons:

3. Urges all States parties to the Treaty on the Non-Proliferation of Nuclear Weapons ${ }^{2}$ to renew their commitment to the urgent and full implementation of their existing obligations under article VI, and calls upon all States to identify and pursue effective measures to fill the legal gap for the prohibition and elimination of nuclear weapons and to cooperate with all stakeholders to achieve this goal;

4. Requests all States possessing nuclear weapons, pending the total elimination of their nuclear weapon arsenals, to take concrete interim measures to reduce the risk of nuclear weapon detonations, including by reducing the operational status of nuclear weapons and moving nuclear weapons away from deployment and into storage, diminishing the role of nuclear weapons in military doctrines and rapidly reducing all types of nuclear weapons;

5. Calls upon all relevant stakeholders, States, international organizations, the International Red Cross and Red Crescent Movement, parliamentarians and civil society to cooperate in efforts to stigmatize, prohibit and eliminate nuclear weapons in the light of their unacceptable humanitarian consequences and associated risks;

6. Decides to include in the provisional agenda of its seventy-first session, under the item entitled "General and complete disarmament", a sub-item entitled "Humanitarian pledge for the prohibition and elimination of nuclear weapons".

'See CD/2039 and www.himw14vienna.at

${ }^{2}$ United Nations, Treary Series, vol. 729, No. 10485. 
The above text speaks for itself and constitutes along with the original Humanitarian (Austrian) Pledge [7], the "Manifesto" of the parties who identify themselves with this bold approach which, again, departs from the historical bi-lateral negotiations between super powers.

It is not difficult to believe, after reading such a compelling and authoritative text, that there is a very strong political will in favour of the abolition of nuclear weapons to be achieved by the means outlined there. Obviously the situation is more complex than can be discussed in this paper however here follows the list of official votes for it at UN General Assembly.

It is extremely interesting to note that the Governments of nuclear-armed states who voted NO to the resolution account for a bare $8 \%$ of world population. Even taking into account the populations of non nuclear-armed states which still voted NO (less than 7\% of world population), the total population living in states which voted no, regardless of their nuclear status, is just a little more than $15 \%$.

The vast majority of people who live in countries whose governments voted either YES or ABSTAIN therefore represents $85 \%$ of the world population. Even taking into account that both the Chinese and Indian Governments abstained (accounting together for 39.4 of world population), the net YES is still from governments accounting for more than $45 \%$ of world population.

\begin{tabular}{|l|r|r|}
\hline $\begin{array}{l}\text { Haves } \\
\text { Who } \\
\text { Voted }\end{array}$ & $\begin{array}{l}\text { Total } \\
\text { Population }\end{array}$ & \% Population \\
\hline A & $2,927,232,737$ & $39.4 \%$ \\
\hline N & $605,530,354$ & $8.2 \%$ \\
\hline Total & $3,532,763,091$ & $47.6 \%$ \\
\hline
\end{tabular}

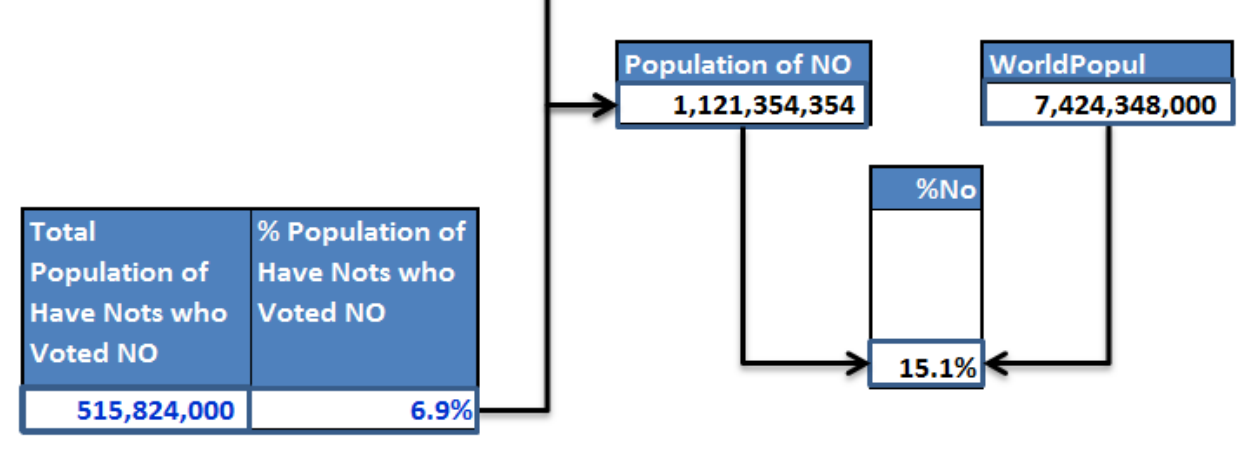

\begin{tabular}{|l|l|l|r|}
\hline Have & V & Country & \multicolumn{1}{|c|}{ Population } \\
\hline Y & A & CHINA & $1,382,323,332$ \\
\hline Y & A & DEMOCRATIC PEOPLE'S REPUBLIC OF KOREA & $25,281,327$ \\
\hline Y & A & INDIA & $1,326,801,576$ \\
\hline Y & A & PAKISTAN & $192,826,502$ \\
\hline Y & N & FRANCE & $64,668,129$ \\
\hline Y & N & ISRAEL & $8,192,463$ \\
\hline Y & N & RUSSIAN FEDERATION & $143,439,832$ \\
\hline Y & N & UNITED KINGDOM & $65,111,143$ \\
\hline Y & N & UNITED STATES & $324,118,787$ \\
\hline
\end{tabular}




\begin{tabular}{|l|r|r|r|}
\hline Have & V & Country & Population \\
\hline N & N & AUSTRALIA & $24,309,330$ \\
\hline N & N & BELGIUM & $11,371,928$ \\
\hline N & N & BULGARIA & $7,097,796$ \\
\hline N & N & CANADA & $36,286,378$ \\
\hline N & N & CROATIA & $4,225,001$ \\
\hline N & N & CZECH REPUBLIC & $10,548,058$ \\
\hline N & N & DENMARK & $5,690,750$ \\
\hline N & N & ESTONIA & $1,309,104$ \\
\hline N & N & GERMANY & $80,682,351$ \\
\hline N & N & HUNGARY & $9,821,318$ \\
\hline N & N & ITALY & $59,801,004$ \\
\hline N & N & LATVIA & $1,955,742$ \\
\hline N & N & LITHUANIA & $2,850,030$ \\
\hline N & N & LUXEMBOURG & 576,243 \\
\hline N & N & MONACO & 37,863 \\
\hline N & N & MONTENEGRO & 626,101 \\
\hline N & N & NETHERLANDS & $16,979,729$ \\
\hline N & N & POLAND & $38,593,161$ \\
\hline N & N & REPUBLIC OF KOREA & $50,503,933$ \\
\hline N & N & ROMANIA & $19,372,734$ \\
\hline N & N & SLOVAKIA & $5,429,418$ \\
\hline N & N & SLOVENIA & $2,069,362$ \\
\hline N & N & SPAIN & $46,064,604$ \\
\hline N & N & TURKEY & $79,622,062$ \\
\hline & & \\
\hline
\end{tabular}

\section{Conclusions}

A possible conclusion to be drawn from this brief paper about the new approaches to total nuclear disarmament is that nuclear weapons are considered a liability rather than an asset by many.

New, apparently minor developments like the steerability and the "dial a yield" feature of the B61-12 nuclear weapon, unknown to the general public ${ }^{4}$, may well have been a wake up call for many concerned politicians because the threshold of use of nuclear weapons might become too low to be a real barrier to use in certain military situations.

The concern is that if the 70+ year old taboo were broken, no real barrier would exist to the field use of nuclear weapons. The first circumscribed "surgical" use, many argue, may well be limited in initial operations. However, nothing, they say, will stop an escalation to megatonnage futher on, and the suvival of mankind itself will be yet again in jeopardy.

\footnotetext{
4 "buried" among other ordinary "routine maintenance" performed under the Stockpile Stewardship and Management Plan [4]
} 
The governments whose populations account for $85 \%$ of the world population, and among them even nuclear armed states, have at least abstained from voting NO to the humanitarian pledge, signalling, in the view of many, that the logic of deterrence is not tantamout to security and that some of the recent attempts to look for a way out of the nuclear (disarmament) impasse (i.e. "modernization" programs) may in fact lead to disaster.

Their desire is to pave the way to nuclear zero before it is too late.

\section{References}

[1] globalsecurity, Russian Military Budget, in Russian Military Budget, 21062016 (retrieved 2016 0728 )

[2] Jon B. Wolfsthal, Jeffrey Lewis, Marc Quint James Martin - Center for Nonproliferation Studies Monterey, California, The Trillion Dollar Nuclear Triad, in The Trillion Dollar Nuclear Triad, January 2014 (retrieved 201607 28)

[3] SIPRI, Global nuclear weapons: downsizing but modernizing, in SIPRI for the media, 13 June 2016 (retrieved 201607 28)

[4] National Nuclear Security Administration United States Department of Energy Washington, DC 20585, Fiscal Year 2016 Stockpile Stewardship and Management Plan, in Report to Congress March 2015. (retrieved 201607 28)

[5] UNFOLD ZERO, Zero nuclear weapons, in Zero nuclear weapons. (retrieved 201607 27)

[6] UNFOLD ZERO, \#LetsTalkNukes - UNFOLD ZERO at the OEWG, in \#LetsTalkNukes UNFOLD ZERO at the OEWG. (retrieved 201607 27)

[7] Austrian Deputy Foreign Minister Michael Linhar, Pledge presented at the Vienna Conference on the Humanitarian Impact of Nuclear Weapons by Austrian Deputy Foreign Minister Michael Linhar, in Pledge, 8-9 December 2014 (retrieved 201607 28) 